\title{
An evidence-based review of edoxaban and its role in stroke prevention in patients with nonvalvular atrial fibrillation
}

This article was published in the following Dove Press journal:

Core Evidence

28 April 2015

Number of times this article has been viewed

\author{
Tushar Acharya \\ Prakash Deedwania \\ Division of Cardiology, Department \\ of Internal Medicine, University of \\ California, San Francisco, Fresno, \\ CA, USA
}

\begin{abstract}
Atrial fibrillation is the most common arrhythmia in the elderly. It is responsible for significant morbidity and mortality from cardioembolic complications like stroke. As a result, atrial fibrillation patients are risk-stratified using the $\mathrm{CHADS}_{2}$ or $\mathrm{CHA}_{2} \mathrm{DS}_{2}-\mathrm{VASc}$ scoring systems. Those at intermediate-to-high risk have traditionally been treated with therapeutic anticoagulation with warfarin for stroke prevention. Although effective, warfarin use is fraught with multiple concerns, such as a narrow therapeutic window, drug-drug and drug-food interactions, and excessive bleeding. Novel oral anticoagulant agents have recently become available as viable alternatives for warfarin therapy. Direct thrombin inhibitor dabigatran and factor Xa inhibitors like rivaroxaban and apixaban have already been approved by the US Food and Drug Administration (FDA) for stroke prevention in patients with nonvalvular atrial fibrillation. Edoxaban is the latest oral direct factor Xa inhibitor studied in the largest novel oral anticoagulant trial so far: ENGAGE AF-TIMI 48. Treatment with a $30 \mathrm{mg}$ or $60 \mathrm{mg}$ daily dose of edoxaban was found to be noninferior to dose-adjusted warfarin in reducing the rate of stroke and systemic embolism in patients with nonvalvular atrial fibrillation, with a lower incidence of bleeding complications and cardiovascular deaths. Edoxaban was recently reviewed by an FDA advisory committee and recommended as a stroke-prophylaxis agent. Once approved, it promises to provide another useful alternative to warfarin therapy.
\end{abstract}

Keywords: atrial fibrillation, stroke prevention, novel oral anticoagulants, factor Xa inhibitors, edoxaban

Clinical impact summary for edoxaban in the stroke prevention in patients with nonvalvular atrial fibrillation

\begin{tabular}{|c|c|c|}
\hline $\begin{array}{l}\text { Outcome } \\
\text { measure }\end{array}$ & Evidence & Implications \\
\hline \multicolumn{3}{|c|}{ Disease-oriented evidence } \\
\hline $\begin{array}{l}\text { Composite of stroke } \\
\text { and systemic } \\
\text { embolism }\end{array}$ & $\begin{array}{l}\mathrm{I} . \mathrm{I} 8 \% \text { per year in patients receiving } 60 \mathrm{mg} \\
\text { edoxaban (HR } 0.79,95 \% \mathrm{Cl} 0.63-0.99 ; \\
P<0.00 \mathrm{I} \text { ) and I. } 61 \% \text { per year in patients } \\
\text { receiving } 30 \mathrm{mg} \text { edoxaban (HR I.07, } \\
95 \% \mathrm{Cl} 0.87-\mathrm{I} .3 \mathrm{I} ; \mathrm{P}=0.005) \text { compared with } \\
\mathrm{I} .50 \% \text { per year in patients receiving dose- } \\
\text { adjusted warfarin }\end{array}$ & $\begin{array}{l}\text { Compared with warfarin, } \\
\text { treatment with edoxaban } \\
\text { at both doses was } \\
\text { noninferior in reducing } \\
\text { the rate of stroke and } \\
\text { systemic embolism in } \\
\text { patients with NVAF }\end{array}$ \\
\hline Stroke & $\begin{array}{l}\text { I.49\% per year in patients receiving } 60 \mathrm{mg} \\
\text { edoxaban (HR } 0.88,95 \% \mathrm{Cl} 0.75-\mathrm{I} .03 ; P=0 . \mathrm{II}) \\
\text { and } \mathrm{I} .9 \mathrm{I} \% \text { per year in patients receiving } 30 \mathrm{mg} \\
\text { edoxaban (HR I.I3,95\% } \mathrm{Cl} 0.97-\mathrm{I} .3 \mathrm{I} ; \mathrm{P}=0.12 \text { ) } \\
\text { compared with } \mathrm{I} .69 \% \text { per year in patients } \\
\text { receiving dose-adjusted warfarin }\end{array}$ & $\begin{array}{l}\text { Compared with warfarin, } \\
\text { treatment with both } \\
\text { doses of edoxaban was } \\
\text { associated with similar } \\
\text { risk of stroke }\end{array}$ \\
\hline
\end{tabular}

(Continued)
Correspondence: Prakash Deedwania UCSF Fresno, Division of Cardiology Academic Offices, 2335 E Kashian Lane, Suite 460, Fresno CA 9370I, USA

Tel +I 5594593943

Fax + I 5594595157

Email pdeedwania@fresno.ucsf.edu 


\begin{tabular}{|c|c|c|}
\hline $\begin{array}{l}\text { (Continued) } \\
\text { Outcome } \\
\text { measure }\end{array}$ & Evidence & Implications \\
\hline Hemorrhagic stroke & $\begin{array}{l}0.26 \% \text { per year in patients receiving } 60 \mathrm{mg} \\
\text { edoxaban ( } \mathrm{HR} 0.54,95 \% \mathrm{Cl} 0.38-0.77 ; P<0.00 \mathrm{I}) \\
\text { and } 0.16 \% \text { per year in patients receiving } 30 \mathrm{mg} \\
\text { edoxaban ( } \mathrm{HR} 0.33,95 \% \mathrm{Cl} 0.22-0.50 ; P<0.00 \mathrm{I}) \\
\text { compared with } 0.47 \% \text { per year in patients } \\
\text { receiving dose-adjusted warfarin }\end{array}$ & $\begin{array}{l}\text { Compared with warfarin, } \\
\text { treatment with either } \\
\text { dose of edoxaban } \\
\text { was associated with a } \\
\text { significantly lower risk of } \\
\text { hemorrhagic stroke }\end{array}$ \\
\hline $\begin{array}{l}\text { Death from } \\
\text { any cause }\end{array}$ & $\begin{array}{l}3.99 \% \text { per year in patients receiving } 60 \mathrm{mg} \\
\text { edoxaban (HR 0.92, } 95 \% \mathrm{Cl} 0.83-\mathrm{I} .0 \mathrm{I} ; \\
P=0.08) \text { and } 3.8 \% \text { per year in patients } \\
\text { receiving } 30 \mathrm{mg} \text { edoxaban (HR } 0.87,95 \% \mathrm{Cl} \\
0.79-0.96 ; P=0.006) \text { compared with } 4.35 \% \\
\text { per year in patients receiving dose-adjusted } \\
\text { warfarin }\end{array}$ & $\begin{array}{l}\text { Compared with warfarin, } \\
\text { treatment with } 60 \mathrm{mg} \\
\text { edoxaban was associated } \\
\text { with marginally lower } \\
\text { risk of death and } 30 \mathrm{mg} \\
\text { edoxaban was associated } \\
\text { with significantly lower risk } \\
\text { of death from any cause }\end{array}$ \\
\hline \multicolumn{3}{|c|}{ Patient-oriented evidence } \\
\hline $\begin{array}{l}\text { ISTH major } \\
\text { bleeding }\end{array}$ & $\begin{array}{l}2.75 \% \text { per year in patients receiving } 60 \\
\text { mg edoxaban }(\mathrm{HR} 0.80,95 \% \mathrm{Cl} 0.7 \mathrm{I}-0.9 \mathrm{I} ; \\
P<0.00 \mathrm{I}) \text { and } \mathrm{I} .6 \mathrm{I} \% \text { per year in patients } \\
\text { receiving } 30 \mathrm{mg} \text { edoxaban }(\mathrm{HR} 0.47,95 \% \mathrm{CI} \\
0.4 \mathrm{I}-0.55 ; P<0.00 \mathrm{I}) \text { compared with } 3.43 \% \\
\text { per year in patients receiving dose-adjusted } \\
\text { warfarin }\end{array}$ & $\begin{array}{l}\text { Compared with warfarin, } \\
\text { treatment with either } \\
\text { dose of edoxaban was } \\
\text { associated with a lower } \\
\text { risk of ISTH major } \\
\text { bleeding }\end{array}$ \\
\hline $\begin{array}{l}\text { Intracranial } \\
\text { bleeding }\end{array}$ & $\begin{array}{l}0.39 \% \text { per year in patients receiving } 60 \\
\text { mg edoxaban (HR } 0.47,95 \% \mathrm{Cl} 0.34-0.63 ; \\
P<0.00 \mathrm{I}) \text { and } 0.26 \% \text { per year in patients } \\
\text { receiving } 30 \mathrm{mg} \text { edoxaban ( } \mathrm{HR} 0.30,95 \% \mathrm{Cl} \\
0.2 \mathrm{I}-0.43 ; P<0.00 \mathrm{I}) \text { compared with } 0.85 \% \\
\text { per year in patients receiving dose-adjusted } \\
\text { warfarin }\end{array}$ & $\begin{array}{l}\text { Compared with warfarin, } \\
\text { treatment with either } \\
\text { dose of edoxaban } \\
\text { was associated with a } \\
\text { significantly lower risk of } \\
\text { intracranial bleeding }\end{array}$ \\
\hline $\begin{array}{l}\text { Gastrointestinal } \\
\text { bleeding }\end{array}$ & $\begin{array}{l}\text { I.5I\% per year in patients receiving } 60 \mathrm{mg} \\
\text { edoxaban (HR I.23, } 95 \% \mathrm{Cl} I .02-\mathrm{I} .50 ; P=0.03) \\
\text { and } 0.82 \% \text { per year in patients receiving } 30 \mathrm{mg} \\
\text { edoxaban (HR 0.67, } 95 \% \mathrm{Cl} 0.53-0.83 ; P<0.00 \mathrm{I}) \\
\text { compared with I.23\% per year in patients } \\
\text { receiving dose-adjusted warfarin }\end{array}$ & $\begin{array}{l}\text { Compared with warfarin, } \\
\text { treatment with } 60 \mathrm{mg} \\
\text { edoxaban had higher } \\
\text { and } 30 \mathrm{mg} \text { edoxaban had } \\
\text { significantly lower risk of } \\
\text { gastrointestinal bleeding }\end{array}$ \\
\hline $\begin{array}{l}\text { Major or clinically } \\
\text { relevant nonmajor } \\
\text { bleeding }\end{array}$ & $\begin{array}{l}\text { I I.I\% per year in patients receiving } 60 \\
\text { mg edoxaban (HR 0.86, 95\% Cl 0.80-0.92; } \\
P<0.00 \text { I) and } 7.97 \% \text { per year in patients } \\
\text { receiving } 30 \mathrm{mg} \text { edoxaban (HR 0.62, } 95 \% \mathrm{Cl} \\
0.57-0.67 ; P<0.00 \mathrm{I}) \text { compared with } 13.02 \% \\
\text { per year in patients receiving dose-adjusted } \\
\text { warfarin }\end{array}$ & $\begin{array}{l}\text { Compared with warfarin, } \\
\text { treatment with edoxaban } \\
\text { at either dose was } \\
\text { associated with a lower } \\
\text { risk of major or clinically } \\
\text { relevant nonmajor } \\
\text { bleeding }\end{array}$ \\
\hline \multicolumn{3}{|c|}{ Net clinical outcome } \\
\hline $\begin{array}{l}\text { Composite of stroke, } \\
\text { systemic embolic } \\
\text { event, major bleeding, } \\
\text { or death from any } \\
\text { cause }\end{array}$ & $\begin{array}{l}7.26 \% \text { per year in patients receiving } 60 \mathrm{mg} \\
\text { edoxaban (HR 0.89, } 95 \% \mathrm{Cl} 0.83-0.96 ; \\
P=0.003) \text { and } 6.79 \% \text { per year in patients } \\
\text { receiving } 30 \mathrm{mg} \text { edoxaban }(\mathrm{HR} 0.83,95 \% \mathrm{Cl} \\
0.77-0.90 ; P<0.00 \mathrm{I}) \text { compared with } 8.11 \% \\
\text { per year in patients receiving dose-adjusted } \\
\text { warfarin }\end{array}$ & $\begin{array}{l}\text { Compared with warfarin, } \\
\text { treatment with either } \\
\text { dose of edoxaban } \\
\text { was associated with } \\
\text { improved net clinical } \\
\text { outcome }\end{array}$ \\
\hline $\begin{array}{l}\text { Composite of } \\
\text { disabling stroke, life- } \\
\text { threatening bleeding, } \\
\text { or death from any } \\
\text { cause }\end{array}$ & $\begin{array}{l}4.64 \% \text { per year in patients receiving } 60 \\
\text { mg edoxaban }(\mathrm{HR} 0.88,95 \% \mathrm{Cl} 0.8 \mathrm{I}-0.97 ; \\
P=0.008) \text { and } 4.38 \% \text { per year in patients } \\
\text { receiving } 30 \mathrm{mg} \text { edoxaban (HR } 0.83,95 \% \mathrm{Cl} \\
0.76-0.9 \mathrm{I} ; \mathrm{P}<0.00 \mathrm{I}) \text { compared with } 5.23 \% \\
\text { per year in patients receiving dose-adjusted } \\
\text { warfarin }\end{array}$ & Same as above \\
\hline
\end{tabular}




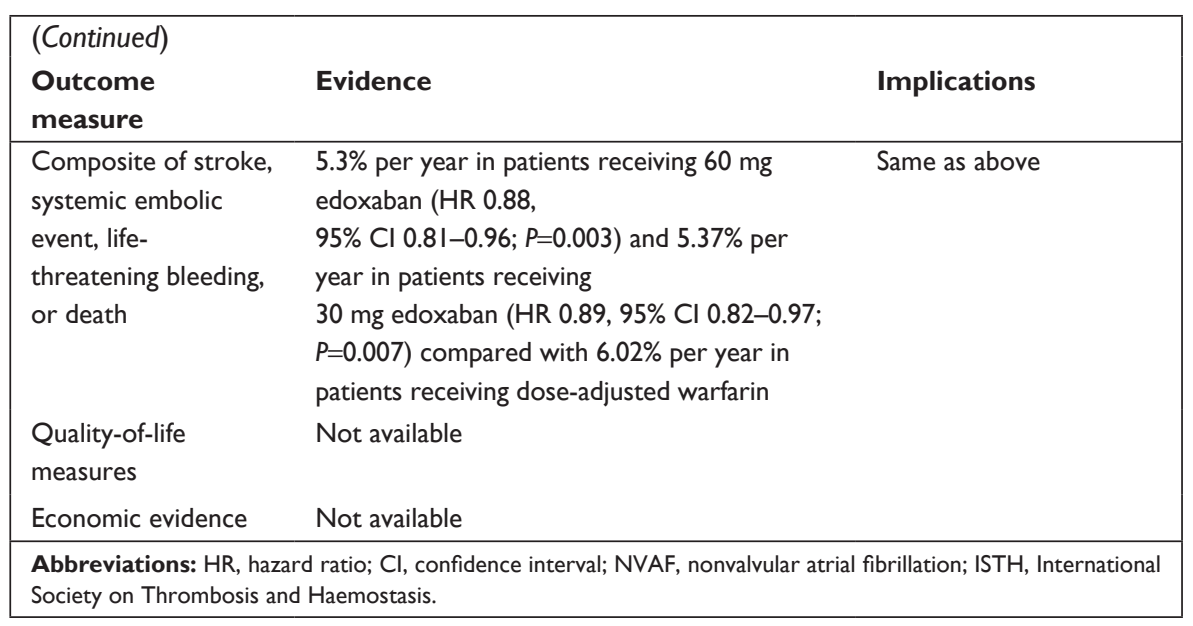

\section{Introduction}

Edoxaban belongs to the family of novel oral anticoagulants (NOACs), and is a direct factor Xa inhibitor. It has been studied in a large Phase III trial (ENGAGE AF-TIMI 48), ${ }^{1}$ and was recently reviewed and recommended for approval by a US Food and Drug Administration (FDA) advisory committee for its use for stroke prevention in patients with atrial fibrillation (AF). AF is the most common arrhythmia encountered in clinical practice. Patients with AF are at a high risk of developing cardioembolic strokes, leading to considerable morbidity and mortality. ${ }^{2,3}$ The vitamin $\mathrm{K}$ antagonist (VKA) warfarin has traditionally been used for stroke prevention in these individuals, but effective use of this medication is encumbered by its delayed onset, narrow therapeutic window, numerous drug-drug and drug-food interactions, and need for regular monitoring. This has prompted the recent advent of newer agents including direct thrombin inhibitors like dabigatran, and factor Xa inhibitors like rivaroxaban and apixaban. Once available, edoxaban promises to be an important addition to the armamentarium of newer OACs for stroke prevention in patients with nonvalvular AF (NVAF).

\section{Atrial fibrillation and risk of stroke}

Patients with AF are susceptible to developing cardioembolic stroke, and are in fact five times as likely to suffer a stroke as patients without AF. ${ }^{4}$ In addition, AF-related strokes have poorer outcomes than non-AF-related strokes, including worse functional impairment, recurrence, and death. ${ }^{5}$

For early identification and better characterization of patients at high risk of developing strokes from AF, multiple risk scores have been developed. The $\mathrm{CHADS}_{2}$ riskscoring system is a well-validated method that utilizes five variables to determine the risk of cardioembolic stroke. ${ }^{6}$ Congestive heart failure, hypertension, diabetes mellitus, and age $\geq 75$ years are each assigned 1 point. History of previous stroke or transient ischemic attack is assigned 2 points. The newer $\mathrm{CHA}_{2} \mathrm{DS}_{2}$-VASc score added three new risk factors (history of vascular disease, age 65-74 years, and female sex) to the risk assessment. ${ }^{7}$ In the $\mathrm{CHA}_{2} \mathrm{DS}_{2}$-VASc scheme, age $\geq 75$ years is assigned 2 points, at par with previous stroke and transient ischemic attack. Therefore, women and elderly patients ( $\geq 75$ years) who were previously identified as at intermediate risk are now placed in the high-risk category, warranting full anticoagulation.

The 2014 American Heart Association (AHA)/American College of Cardiology (ACC) AF guidelines recommend the use of $\mathrm{CHA}_{2} \mathrm{DS}_{2}$-VASc scoring system in place of $\mathrm{CHADS}_{2}$ for stroke-risk assessment. ${ }^{8}$ For high-risk patients with NVAF ( $\mathrm{CHA}_{2} \mathrm{DS}_{2}$-VASc score $\geq 2$ ), oral anticoagulation therapy is given the strongest (class I) recommendation. For patients with an intermediate-risk score of 1 , options of anticoagulation, aspirin, or no therapy are left to the discretion of the provider (class IIb). In low-risk patients with a risk score of 0 , no antithrombotic therapy is considered reasonable (class IIa).

\section{Vitamin $\mathrm{K}$ antagonist for stroke prevention}

The VKA warfarin has traditionally been used for patients with AF, and has been shown to reduce the risk of stroke and mortality. ${ }^{9}$ However, effective use of this medication is fraught with multiple impediments, contributing to significant underutilization. ${ }^{10}$ Warfarin has a slow onset of action, narrow therapeutic window, variable cytochrome P450-dependent metabolism, and significant drug-drug and drug-food interactions. ${ }^{10-13}$ As a result, anticoagulation with warfarin is unreliable, necessitating the need for frequent and regular international normalized ratio (INR) monitoring and dosage adjustment. The therapeutic window for warfarin is narrow. Subtherapeutic anticoagulation exposes patients to 
cardioembolic events, and supratherapeutic anticoagulation subjects them to bleeding complications. ${ }^{14}$ Unfortunately, in most patients, therapeutic anticoagulation is maintained less than a third of the time. Even in recent randomized control trials, where concerted efforts were made to keep most patients at the target INR, the time in therapeutic range was able to be maintained only in $62 \%-64 \%$ of patients. In the ROCKET-AF trial, time in therapeutic range was merely $55 \%$. In addition, frequent doctor and laboratory visits make warfarin therapy expensive and inconvenient. ${ }^{15}$

Elderly patients with cognitive impairment, physical limitations, and frequent falls are especially vulnerable to bleeding risk with warfarin. Another high-risk group is patients with severe renal impairment. Not only are these patients at an increased risk of strokes but they are also prone to increased bleeding with warfarin therapy, due to underlying plateletdysfunction and coagulation-pathway abnormalities. ${ }^{16-18}$

Since the 1950s, warfarin has been the main OAC available for AF patients. There has been a need for newer OACs that would have a rapid onset of action, insignificant drug-drug and drug-food interactions, and provide reliable stroke prevention by having a predictable effect, without the need for frequent monitoring.

\section{Antiplatelet agents}

Though dose-adjusted warfarin is significantly more effective than antiplatelet therapy (meta-analysis of 12 trials $[n=12,963]$ showed relative risk reduction of $39 \%$ [confidence interval $\{\mathrm{CI}\} 22 \%-52 \%$ ]), ${ }^{19}$ antiplatelet agents have long been used as an alternative in patients deemed to be at low risk of stroke or with contraindications to warfarin. Aspirin use was given a class I recommendation for use in patients with a $\mathrm{CHADS}_{2}$ score of 0 and class IIa recommendation patients with a $\mathrm{CHADS}_{2}$ score of 1 as per 2006 ACC/AHA AF guidelines. ${ }^{20}$ However, over time, evidence has accumulated against aspirin use for this indication. A meta-analysis by Hart et al ${ }^{19}$ looked at seven trials $(n=3,990)$ comparing aspirin at different doses to placebo/no treatment for primary and secondary stroke prevention in patients with $\mathrm{AF}$, and found no significant difference other than in one trial (SPAF-121). Risk reduction of $19 \%$ (CI $-1 \%$ to $35 \%$ ) was seen with aspirin, but the CI encompassing 0 questioned any real benefit at all.

Additionally, the AVERROES trial ${ }^{22}$ showed that in patients unsuitable for warfarin therapy, the factor $\mathrm{Xa}$ inhibitor apixaban reduced almost 50\% more strokes than aspirin (relative risk [RR] 0.46 [95\% CI 0.33-0.64]) during a 1-year follow-up.
The 2014 AF guidelines have thus moved away from aspirin for stroke prevention. No antithrombotic use is now considered reasonable for patients with a $\mathrm{CHA}_{2} \mathrm{DS}_{2}-\mathrm{VASc}$ score of 0 (class IIa), and the use of aspirin may be considered for $\mathrm{CHA}_{2} \mathrm{DS}_{2}$-VASc score of 1 (class IIB). ${ }^{8}$

Dual-antiplatelet therapy with aspirin and clopidogrel as an alternative to warfarin in patients with a $\mathrm{CHADS}_{2}$ score $\geq 1$ was evaluated in the ACTIVE $\mathrm{W}$ trial. ${ }^{23}$ The trial was stopped early, due to marked superiority of warfarin over dual antiplatelets (RR 1.44 [95\% CI 1.18-1.76]; $P=0.0003$ ) for stroke prevention. The ACTIVE A (a separate arm of ACTIVE W) trial found that dual-antiplatelet therapy prevented more strokes than aspirin alone, but also caused significantly more bleeding. ${ }^{24}$ Based on these trials, the 2011 ACC/AHA focused update of the 2006 AF guidelines gave combination therapy with aspirin and clopidogrel a class $\mathrm{IIb}$ recommendation for stroke prevention in patients unwilling or unsuitable for anticoagulant therapy. ${ }^{25}$ However, dual-antiplatelet therapy has not been given any recommendation in the 2014 guidelines.

\section{Novel oral anticoagulant agents Direct thrombin inhibitors}

Dabigatran is a direct thrombin inhibitor. It was the first NOAC approved by the FDA for stroke prevention in patients with NVAF. The RE-LY study ${ }^{26}$ was a multicenter, randomized trial that tested the efficacy and safety of $110 \mathrm{mg}$ twice a day and $150 \mathrm{mg}$ twice a day dosing of dabigatran etexilate with open-label dose-adjusted warfarin in 18,113 patients. After a mean follow-up of 2 years, dabigatran $150 \mathrm{mg}$ twice a day was found to be superior in efficacy (stroke and systemic embolic event [SEE] prevention) with similar major bleeding as warfarin, and $110 \mathrm{mg}$ twice a day was found to be noninferior in efficacy with less major bleeding than warfarin. Both doses showed less intracranial bleeding than warfarin. However, rates of myocardial infarction and adverse effects like dyspepsia were somewhat higher in the dabigatran groups. Based on these results, the FDA in October 2010 approved the $150 \mathrm{mg}$ twice-a-day regimen (as well as $75 \mathrm{mg}$ twice a day for patients with severe renal impairment) for stroke prevention in AF patients. A Canadian regulatory authority, the European Medicines Agency, and many other authorities worldwide approved both $150 \mathrm{mg}$ and $110 \mathrm{mg}$ twice-daily dosing of the drug.

Soon after dabigatran's approval, there were postmarketing reports of increased gastrointestinal, intracranial, and fatal bleeds. In response, the FDA did a mini-sentinel analysis of insurance claims and administrative data, but 
found no increased bleeding with dabigatran compared to warfarin. ${ }^{27}$ The RELY-ABLE study followed $48 \%$ of patients originally assigned to dabigatran in the RE-LY study for an additional 2.3 years, and found a higher rate of major bleeding with dabigatran $150 \mathrm{mg}$ twice daily in comparison with $110 \mathrm{mg}$, with similar rates of stroke and death. ${ }^{28}$ Use of dabigatran has received a class I indication in the 2014 ACC/ AHA AF guidelines for stroke prevention in patients with a $\mathrm{CHA}_{2} \mathrm{DS}_{2}$-VASs score of $\geq 2$ and in patients unable to maintain a therapeutic INR. Lower-dose direct thrombin inhibitors may be considered for patients with moderate-to-severe chronic kidney disease (class IIb). They should not be used in patients with end-stage renal disease or with mechanical valves (class III). ${ }^{8}$

\section{Factor Xa inhibitors}

The coagulation cascade involves stepwise amplification with one molecule of factor Xa generating a thousand molecules of thrombin. ${ }^{29}$ Two factor Xa inhibitors - rivaroxaban and apixaban - have been approved by the FDA for stroke prevention in AF.

Rivaroxaban was evaluated for stroke prevention in moderate- to high-risk AF patients in the ROCKET-AF trial. ${ }^{30}$ This large multicenter trial $(n=14,264$, median follow-up 1.9 years) showed rivaroxaban at a $15-20 \mathrm{mg}$ daily dose to be noninferior to dose-adjusted warfarin in preventing stroke and SEEs. There was no difference in major and minor bleeding rates between the groups, though intracranial bleeding was less and gastrointestinal bleeding was more with rivaroxaban. Despite concerns about once-a-day administration of a drug with a relatively short half-life, rivaroxaban was approved by the FDA for stroke prevention for AF patients in November 2011. Another concern with rivaroxaban was a much higher rate of stroke or systemic embolism seen compared to warfarin (31 versus 12 detected events) between days 2 and 7 after discontinuation of randomized treatment. ${ }^{31}$

Apixaban was the second factor $\mathrm{Xa}$ inhibitor that was evaluated in two major randomized control trials. The AVERROES trial randomized 5,600 patients unsuitable for VKA therapy due to difficult-to-control INR or bleeding to apixaban $5 \mathrm{mg}$ twice a day or aspirin 81-324 mg daily. ${ }^{22}$ The study was terminated early after a median follow-up of 1 year. Apixaban reduced significantly more strokes than aspirin (RR 0.46, 95\% CI 0.33-0.64). Subsequently, apixaban $5 \mathrm{mg}$ twice a day was compared to dose-adjusted warfarin in the ARISTOTLE trial. ${ }^{32}$ This double-blinded randomized control trial ( $\mathrm{n}=18,201$, median follow-up 1.8 years) showed that apixaban was superior to warfarin in stroke and SEE prevention, with significantly lower overall and intracranial bleeding and significantly lower all-cause mortality. Based on these trials, apixaban was approved by the FDA for stroke prevention in December 2012.

The use of factor $\mathrm{Xa}$ and thrombin inhibitors was endorsed by the 2012 ESC update of AF guidelines, where they received a class I indication for use for stroke prevention in AF patients and IIa recommendation for preferential use over dose-adjusted warfarin. ${ }^{33}$ Similarly, the Canadian Cardiovascular Society and American Academy of Neurology gave favorable recommendations for their use in their 2012 AF guidelines update. ${ }^{34,52}$ Dabigatran, rivaroxaban, and apixaban received a class I indication in the 2014 ACC/ AHA AF guidelines for stroke prevention in patients with a $\mathrm{CHA}_{2} \mathrm{DS}_{2}$-VASs score of $\geq 2$ and in patients unable to maintain a therapeutic INR. ${ }^{8}$

The newest addition to the family of NOACs and the class of factor Xa inhibitors, edoxaban is currently undergoing FDA review. The following is a brief review of edoxaban for stroke prevention in NVAF.

\section{Edoxaban - brief pharmacology}

Edoxaban is a rapidly acting, oral, selective factor $\mathrm{Xa}$ inhibitor. It is readily absorbed from the intestines, and has a $62 \%$ oral bioavailabilty. ${ }^{35}$ Diet has no clinically significant effect on edoxaban activity ${ }^{36}$ and it reaches plasma peak concentration and anti-factor Xa activity in 1-2 hours. ${ }^{37,38}$ Edoxaban has a half-life of 10-14 hours, but its anti-factor Xa activity remains above baseline for 24 hours. Seventy percent of the drug is excreted unchanged in urine and feces. ${ }^{39}$

Edoxaban is a substrate of P-glycoprotein (P-gp), ${ }^{40}$ and coadministration of potent $\mathrm{P}$-gp inhibitors like quinidine, verapamil, and dronedarone increases edoxaban exposure. ${ }^{41}$ Accordingly, in the ENGAGEAF-TIMI 48 trial, patients taking these medications were administered half doses of edoxaban. Low-dose aspirin and nonsteroidal anti-inflammatory drugs like naproxen are well tolerated in patients receiving edoxaban. ${ }^{42}$ Edoxaban can also be safely administered after 12 hours of enoxaparin use. ${ }^{43}$

\section{Edoxaban: clinical trials in stroke prevention Phase I clinical trials}

In a safety, tolerability, pharmacokinetic, and pharmacodynamic study, 85 healthy volunteers received a single dose $(10,30,60,90,120$, or $150 \mathrm{mg}$ once only) and 36 volunteers received multiple doses of edoxaban (90 mg daily, $120 \mathrm{mg}$ daily, or $60 \mathrm{mg}$ twice a day). ${ }^{38}$ Plasma concentrations of 
edoxaban were proportional to the dose, with low intersubject variability. Elevation of activated partial thromboplastin time, prothrombin time and INR, and reduction in activated factor $\mathrm{X}$ activity were seen within the first few hours of administration and returned to baseline in 24 to 36 hours. Edoxaban was well tolerated in both groups, and no dose-dependent increase in serious adverse events was documented.

\section{Phase II clinical trials}

In a multicenter, multinational Phase II clinical trial of edoxaban, four doses (30 mg daily, $60 \mathrm{mg}$ daily, $30 \mathrm{mg}$ twice a day, and 60 mg twice a day) were compared with dose-adjusted warfarin (target INR 2-3) in 1,146 patients with NVAF. ${ }^{44}$ Patients randomized to one of the five groups were followed for 12 weeks to look for incidence of major and nonmajor bleeding. Bleeding rates were similar in patients on once-a-day dosage of edoxaban $3.0 \%$ in $30 \mathrm{mg}$ daily and $3.8 \%$ in $60 \mathrm{mg}$ daily) to those on dose-adjusted warfarin $(3.2 \%)$, but significantly higher in those on twice-aday dosing (7.8\% in $30 \mathrm{mg}$ twice daily and $10.6 \% 60 \mathrm{mg}$ twice daily). Based on these results, a once-daily dosing of edoxaban was selected for Phase III clinical trials. Daily dosages of 30, 45 , and $60 \mathrm{mg}$ of edoxaban were compared to dose-adjusted warfarin in another trial in 536 Japanese patients with NVAF. ${ }^{45}$ No statistically significant difference was found in symptomatic and asymptomatic bleeding at 12 weeks of follow-up. On the basis of exposure-response modeling and pharmacokinetics from 1,281 subjects, $30 \mathrm{mg}$ and $60 \mathrm{mg}$ once-daily doses of edoxaban were chosen to undergo Phase III trials, with 50\% dose reductions for moderate renal impairment or concomitant P-gp inhibitor use. ${ }^{46}$

\section{Phase III clinical trial}

The efficacy and safety of edoxaban compared to warfarin was evaluated in the ENGAGE AF-TIMI 48 trial. ${ }^{1}$ This was a large multicenter, randomized, double-blind, double-dummy trail that enrolled 21,105 patients at 1,393 hospitals from 46 countries. A noninferiority study design was used to compare two oral doses of edoxaban (30 mg and $60 \mathrm{mg}$ daily) to warfarin in patients with $\mathrm{AF}$ and moderate-to-high risk of stroke.

Patients were enrolled during a 2-year period from November 2008 through November 2010. The study population included patients $\geq 21$ years of age, with AF documented within 1 year preceding randomization and a $\mathrm{CHADS}_{2}$ score of 2 or more. Principal exclusion criteria included transient AF secondary to a reversible cause, creatinine clearance of $<30 \mathrm{~mL} / \mathrm{min}$, use of dual-antiplatelet therapy, high bleeding risk, moderate-to-severe mitral stenosis, mechanical heart valves, other indications for anticoagulation, stroke, acute coronary syndrome, or percutaneous coronary intervention within the previous 30 days, pregnancy, malignancy, and life expectancy $<12$ months, among others. ${ }^{47}$

Patients were randomized in a 1:1:1 fashion to a daily oral dose of $30 \mathrm{mg}$ (low exposure) or $60 \mathrm{mg}$ (high exposure) edoxaban or warfarin titrated to an INR of $2-3 .^{2}$ In patients with moderate renal dysfunction (creatinine clearance $30-50 \mathrm{~mL} / \mathrm{min}$ ), body weight less than $60 \mathrm{~kg}$ or concomitant use of potent P-gp inhibitors (verapamil, quinidine, or dronedarone), a dose reduction of $50 \%$ to the edoxaban arms was instituted to prevent excess bleeding. According to the double-dummy design, patients on edoxaban received placebo-matching warfarin and patients on warfarin received placebo-matching edoxaban. Additionally, patients in the edoxaban arms had sham blood draws for INR checks. Regular INR checks and clinic visits were carried out.

Efficacy and safety outcomes were evaluated. The primary efficacy end point was a composite of stroke (ischemic or hemorrhagic) and SEEs. The primary safety end point was major bleeding as per the International Society on Thrombosis and Hemostasis, defined as meeting one or more of the following criteria: fatal bleeding, symptomatic bleeding in a critical area or organ, or clinically overt bleeding causing a $\geq 2.0 \mathrm{~g} / \mathrm{dL}$ drop in hemoglobin. Stroke, systemic embolism, cardiac death, and all-cause death were assessed separately and in combination for secondary end points. Bleeding at different locations, of varying intensity, and defined by other definitions was also assessed. An independent clinical end-point committee that was blinded to study assignment adjudicated all events.

The median age of the study population was 72 years, and their mean $\mathrm{CHADS}_{2}$ score was 2.8. Patients randomized to warfarin were in the therapeutic range $68.4 \%$ of the time. Both groups were comparable in terms of their baseline characteristics (Table 1). After a median follow-up of 2.8 years, the annual rate of primary outcome (stroke and/or SEE) for patients in the high-dose edoxaban group was $1.18 \%$ (hazard ratio [HR] 0.79, 97.5\% CI 0.63-0.99; $P<0.001$ for noninferiority, $P=0.02$ for superiority), and for patients in the low-dose edoxaban group was $1.61 \%$ (HR 1.07, 97.5\% CI 0.87-1.31; $P=0.005$ for noninferiority, $P=0.44$ for superiority) compared to $1.5 \%$ in the warfarin group (Table 2 ). Hemorrhagic stroke rates were significantly lower than warfarin $(0.47 \%)$ in both the high-dose $(0.26 \%)$ and low-dose edoxaban $(0.16 \%)$ groups. A subsequent subanalysis of all cerebrovascular events showed that the rates of ischemic stroke or transient ischemic attack were similar with high-dose edoxaban (1.76\% per year) and warfarin $(1.73 \%$ per year) $(P=0.81)$, but more frequent with low-dose edoxaban $(2.48 \%$ per year, 
Table I Baseline characteristics of patients in ENGAGE AF-TIMI 48 trial

\begin{tabular}{|c|c|c|c|}
\hline Variable & $\begin{array}{l}\text { Warfarin } \\
(n=7,036)\end{array}$ & $\begin{array}{l}\text { High-dose } \\
\text { edoxaban } \\
(n=7,035)\end{array}$ & $\begin{array}{l}\text { Low-dose } \\
\text { edoxaban } \\
(n=7,034)\end{array}$ \\
\hline Median age, years & 72 & 72 & 72 \\
\hline Female sex, n (\%) & $2,64 I(37.5)$ & $2,669(37.9)$ & $2,730(38.8)$ \\
\hline \multicolumn{4}{|c|}{ Qualifying risk factors, n (\%) } \\
\hline Age $\geq 75$ years & $2,820(40.1)$ & $2,848(40.5)$ & $2,806(39.9)$ \\
\hline Prior stroke or TIA & $1,991(28.3)$ & $1,976(28.1)$ & $2,006(28.5)$ \\
\hline Congestive heart failure & $4,048(57.5)$ & $4,097(58.2)$ & $3,979(56.6)$ \\
\hline Diabetes mellitus & $2,521(35.8)$ & $2,559(36.4)$ & $2,544(36.2)$ \\
\hline Hypertension & $6,588(93.6)$ & $6,591(93.7)$ & $6,575(93.5)$ \\
\hline \multicolumn{4}{|l|}{$\mathrm{CHADS}_{2}$ score } \\
\hline Mean score \pm SD & $2.8 \pm 1.0$ & $2.8 \pm 1.0$ & $2.8 \pm 1.0$ \\
\hline $2-3, \mathrm{n}(\%)$ & $5,445(77.4)$ & $5,422(77.1)$ & $5,470(77.8)$ \\
\hline $4-6, n(\%)$ & I,59| (22.6) & $\mathrm{I}, 6 \mathrm{I3}(22.9)$ & $\mathrm{I}, 564(22.2)$ \\
\hline
\end{tabular}

Note: From N Engl I Med, Giugliano RP, Ruff CT, Braunwald E, et al. Edoxaban versus warfarin in patients with atrial fibrillation. 369:2093-2104. Copyright @ 2013. Adapted with permission from Massachusetts Medical Society.'

Abbreviations: TIA, transient ischemic attack; SD, standard deviation.

$P<0.001) .{ }^{48}$ Cardiovascular deaths were significantly lowered with high-dose (HR 0.86, 95\% CI 0.77-0.97; $P=0.01$ ) and low-dose edoxaban use (HR $0.85,95 \%$ CI $0.76-0.96$; $P=0.008)$ when compared to warfarin. A similar trend was seen in all-cause death reduction, which reached statistical significance only in the low-dose edoxaban group (HR 0.87, 95\% CI 0.79-0.96; $P=0.006$ ). There was no significant difference in myocardial infarction between groups.

With regard to the safety-outcome measures, major bleeding was significantly less with both doses of edoxaban. Compared to an event rate of $3.43 \%$ in the warfarin group, the high-dose edoxaban group had a major bleeding rate of $2.75 \%$ (HR $0.80,95 \%$ CI $0.71-0.91 ; P<0.001$ ) and the lowdose group had a rate of $1.61 \%$ (HR $0.47,95 \%$ CI $0.41-0.55$; $P<0.001$ ) (Table 2). Fatal and intracranial bleeds were less than warfarin in the high-dose edoxaban (HR 0.55 and 0.47 , respectively) and low-dose edoxaban groups (HR 0.35 and 0.30 , respectively). Risk of gastrointestinal bleeding was increased in the high-dose edoxaban (HR 1.23) but reduced in the low-dose edoxaban group (HR 0.67) when compared to warfarin. Tolerability and adverse events with both doses of edoxaban and warfarin were comparable.

\section{Comparison of edoxaban and other newer novel oral anticoagulant agents}

Pharmacological characteristics of the four NOACs are described in Table $3{ }^{49}$ All four NOACs have been evaluated in large Phase III randomized control trials. Edoxaban $60 \mathrm{mg}$ daily, apixaban $5 \mathrm{mg}$ twice a day, and dabigatran $150 \mathrm{mg}$ twice a day were shown to be superior to dose-adjusted warfarin in stroke and SEE prevention. Edoxaban $30 \mathrm{mg}$ daily, rivaroxaban $20 \mathrm{mg}$ daily, and dabigatran $110 \mathrm{mg}$ twice a day were found to be noninferior. The benefits of newer anticoagulants over warfarin were driven by a significant reduction in hemorrhagic strokes (reduced to half)..$^{50}$ Major bleeding rates were comparable to warfarin for dabigatran $150 \mathrm{mg}$ twice a day and rivaroxaban $20 \mathrm{mg}$ daily. Edoxaban $30 \mathrm{mg}$ and $60 \mathrm{mg}$ daily, apixaban $5 \mathrm{mg}$ twice a day, and dabigatran $110 \mathrm{mg}$ twice a day had lower major bleeding rates than warfarin. Intracranial bleeding was

Table 2 Results of the ENGAGE AF-TIMI 48 trial

\begin{tabular}{|c|c|c|c|c|c|c|c|}
\hline & \multirow[t]{2}{*}{$\begin{array}{l}\text { Warfarin } \\
\text { event rate }\end{array}$} & \multirow{2}{*}{$\begin{array}{l}\text { High-dose } \\
\text { edoxaban } \\
\text { event rate }\end{array}$} & \multirow{2}{*}{$\begin{array}{l}\text { Low-dose } \\
\text { edoxaban } \\
\text { event rate }\end{array}$} & \multicolumn{2}{|c|}{$\begin{array}{l}\text { High-dose edoxaban } \\
\text { versus warfarin }\end{array}$} & \multicolumn{2}{|c|}{$\begin{array}{l}\text { Low-dose edoxaban } \\
\text { versus warfarin }\end{array}$} \\
\hline & & & & $\begin{array}{l}\text { Hazard ratio } \\
(95 \% \mathrm{Cl})\end{array}$ & $P$-value & $\begin{array}{l}\text { Hazard ratio } \\
(95 \% \mathrm{Cl})\end{array}$ & $P$-value \\
\hline \multicolumn{8}{|l|}{ Efficacy outcomes } \\
\hline $\begin{array}{l}\text { Stroke or systemic embolic } \\
\text { event (primary) (noninferiority) }\end{array}$ & 1.50 & 1.18 & 1.61 & $0.79(0.63-0.99)$ & $<0.001$ & I.07 (0.87-I.3I) & 0.005 \\
\hline Stroke & 1.69 & 1.49 & 1.91 & $0.88(0.75-1.03)$ & 0.11 & I.I3 (0.97-I.3I) & 0.12 \\
\hline Hemorrhagic stroke & 0.47 & 0.26 & 0.16 & $0.54(0.38-0.77)$ & $<0.001$ & $0.33(0.22-0.50)$ & $<0.001$ \\
\hline $\begin{array}{l}\text { Stroke, systemic embolism or } \\
\text { death from cardiovascular cause }\end{array}$ & 4.43 & 3.85 & 4.23 & $0.87(0.78-0.96)$ & 0.005 & $0.95(0.86-1.05)$ & 0.32 \\
\hline Death from any cause & 4.35 & 3.99 & 3.80 & $0.92(0.83-1.01)$ & 0.08 & $0.87(0.79-0.96)$ & 0.006 \\
\hline Death from cardiovascular cause & 3.17 & 2.74 & 2.71 & $0.86(0.77-0.97)$ & 0.013 & $0.85(0.76-0.96)$ & 0.008 \\
\hline \multicolumn{8}{|l|}{ Safety outcomes } \\
\hline ISTH major bleeding (primary) & 3.43 & 2.75 & 1.61 & $0.80(0.7 \mid-0.9 I)$ & $<0.001$ & $0.47(0.4 I-0.55)$ & $<0.001$ \\
\hline Fatal & 0.38 & 0.21 & 0.13 & $0.55(0.36-0.84)$ & 0.006 & $0.35(0.21-0.57)$ & $<0.001$ \\
\hline Intracranial & 0.85 & 0.39 & 0.26 & $0.47(0.34-0.63)$ & $<0.001$ & $0.30(0.21-0.43)$ & $<0.001$ \\
\hline Gastrointestinal & 1.23 & 1.51 & 0.82 & $1.23(1.02-1.50)$ & 0.03 & $0.67(0.53-0.83)$ & $<0.001$ \\
\hline
\end{tabular}

Note: From N Engl J Med, Giugliano RP, Ruff CT, Braunwald E, et al. Edoxaban versus warfarin in patients with atrial fibrillation. 369:2093-2I04. Copyright (C 20I3. Adapted with permission from Massachusetts Medical Society.'

Abbreviations: $\mathrm{Cl}$, confidence interval; ISTH, International Society on Thrombosis and Haemostasis. 
Table 3 Comparison of pharmacological properties and overview of study design of Phase III randomized clinical trials of new oral anticoagulants

\begin{tabular}{|c|c|c|c|c|}
\hline & Dabigatran & Rivaroxaban & Apixaban & Edoxaban \\
\hline Mechanism of action & $\begin{array}{l}\text { Direct thrombin } \\
\text { inhibitor }\end{array}$ & $\begin{array}{l}\text { Direct factor } \\
\text { Xa inhibitor }\end{array}$ & Direct factor $\mathrm{Xa}$ inhibitor & Direct factor $\mathrm{Xa}$ inhibitor \\
\hline Oral bioavailability, \% & 6.5 & $80-100$ & 50 & 62 \\
\hline Onset of action, hours & $\mathrm{I}-2$ & $0.5-3$ & $3-4$ & $\mathrm{I}-2$ \\
\hline Half-life, hours & $12-17$ & $5-13$ & $8-15$ & $10-14$ \\
\hline Renal elimination, \% & 85 & $\begin{array}{l}66 \text { ( } 36 \text { unchanged } \\
\text { and } 30 \text { inactive } \\
\text { metabolites) }\end{array}$ & 27 & 50 \\
\hline $\begin{array}{l}\text { Time to maximum } \\
\text { inhibition, hours }\end{array}$ & $0.5-2$ & $\mathrm{I}-4$ & $\mathrm{I}-4$ & $\mathrm{I}-2$ \\
\hline Protein binding & 35 & $92-95$ & 87 & 55 \\
\hline Interaction with food & Minimal & Minimal & Minimal & Minimal \\
\hline $\begin{array}{l}\text { Interaction with } \\
\text { amiodarone }\end{array}$ & $\begin{array}{l}\text { Yes, use with } \\
\text { caution }\end{array}$ & $\begin{array}{l}\text { Yes, avoidance } \\
\text { recommended }\end{array}$ & Yes, avoidance recommended & Yes, use with caution \\
\hline $\begin{array}{l}\text { Interaction with } \\
\text { dronedarone }\end{array}$ & $\begin{array}{l}\text { Yes, avoidance } \\
\text { recommended }\end{array}$ & $\begin{array}{l}\text { Yes, avoidance } \\
\text { recommended }\end{array}$ & Yes, avoidance recommended & Yes, dose reduction recommended \\
\hline $\begin{array}{l}\text { Interaction with } \\
\text { verapamil }\end{array}$ & $\begin{array}{l}\text { Yes, dose reduction } \\
\text { recommended }\end{array}$ & $\begin{array}{l}\text { Yes, use with } \\
\text { caution }\end{array}$ & Yes, use with caution & Yes, dose reduction recommended \\
\hline $\begin{array}{l}\text { Regular lab } \\
\text { monitoring required }\end{array}$ & No & No & No & No \\
\hline Reversal agent & No & No & No & PER977 (potential) \\
\hline Phase III clinical trial & RELY & ROCKET & ARISTOTLE & ENGAGE AF \\
\hline Sample size & 18,113 & 14,264 & $|8,20|$ & 21,107 \\
\hline $\begin{array}{l}\text { New treatment } \\
\text { and dose }\end{array}$ & $\begin{array}{l}\text { I I0 mg BID and } \\
\text { I50 mg BID }\end{array}$ & 20 mg daily & $5 \mathrm{mg}$ BID & $30 \mathrm{mg}$ daily and $60 \mathrm{mg}$ daily \\
\hline Dose adjustment & No & $\begin{array}{l}\text { At randomization, } \\
15 \mathrm{mg} \text { for } \mathrm{CrCl} \\
30-49 \mathrm{~mL} / \mathrm{min}\end{array}$ & $\begin{array}{l}\text { At randomization, half dose for two } \\
\text { or more of following: age } \geq 80 \text { years, } \\
\text { weight } \leq 60 \mathrm{~kg}, \mathrm{Cr} \geq \mathrm{I} .5 \mathrm{mg} / \mathrm{dL}\end{array}$ & $\begin{array}{l}\text { During trial, half dose for } \mathrm{CrCl} \\
30-50 \mathrm{~mL} / \mathrm{min} \text {, weight }<60 \mathrm{~kg} \text { or use } \\
\text { of potent P-glycoprotein inhibitors }\end{array}$ \\
\hline Design & $\begin{array}{l}\text { Noninferiority, } \\
\text { open-label with blinded } \\
\text { event adjudication }\end{array}$ & $\begin{array}{l}\text { Noninferiority, } \\
\text { double-blind }\end{array}$ & Noninferiority, double-blind & Noninferiority, double-blind \\
\hline Patients & $\mathrm{CHADS}_{2}$ score $\geq \mathrm{I}$ & $\begin{array}{l}\text { CHADS }_{2} \\
\text { score } \geq 2\end{array}$ & $\mathrm{CHADS}_{2}$ score $\geq 1$ & $\mathrm{CHADS}_{2}$ score $\geq 2$ \\
\hline Primary outcome & $\begin{array}{l}\text { Stroke or systemic } \\
\text { embolism }\end{array}$ & $\begin{array}{l}\text { Stroke or systemic } \\
\text { embolism }\end{array}$ & Stroke or systemic embolism & Stroke or systemic embolism \\
\hline Safety outcome & Major bleeding & Major bleeding & Major bleeding & Major bleeding \\
\hline FDA approval & Yes & Yes & Yes & Pending \\
\hline
\end{tabular}

Abbreviations: $\mathrm{BID}$, bis in die (twice a day); $\mathrm{CrCl}$, creatinine clearance; FDA, US Food and Drug Administration.

lower with NOACs across the board. Edoxaban and apixaban were the only two to show mortality benefit when compared to warfarin. NOACs as a group were compared to dose-adjusted warfarin in a recent meta-analysis (Table 4)..$^{50}$ There has not been a head-to-head comparison of the NOACs.

Dabigatran $150 \mathrm{mg}$ twice a day was approved by the FDA in 2010. Subsequent reports of increased bleeding with its use were somewhat dispelled by a mini-sentinel analysis by the FDA; however, higher major bleeding rates documented on long-term follow-up are concerning. ${ }^{28}$ Rivaroxaban $20 \mathrm{mg}$ once a day was approved in 2011 for stroke prevention. The once-daily dosing of rivaroxaban was criticized by the FDA for not being supported by pharmacokinetic and pharmacodynamic data. Apixaban $5 \mathrm{mg}$ twice a day was
Table 4 Comparative analysis of the novel anticoagulant agents in meta-analysis when compared against dose-adjusted warfarin

\begin{tabular}{lll}
\hline & $\begin{array}{l}\text { Stroke or systemic } \\
\text { embolic events, } \\
\text { RR }(95 \% \mathrm{CI}), \mathbf{P}\end{array}$ & $\begin{array}{l}\text { Major bleeding, } \\
\mathbf{R R}(\mathbf{9 5} \% \mathrm{CI}), \mathbf{P}\end{array}$ \\
\hline RELY (dabigatran & $0.66(0.53-0.82)$, & $0.94(0.82-\mathrm{I} .07)$, \\
I50 mg twice daily) & $0.000 \mathrm{I}$ & 0.34 \\
ROCKET (rivaroxaban & $0.88(0.75-\mathrm{I} .03)$, & $\mathrm{I} .03(0.90-\mathrm{I} .18)$, \\
$20 \mathrm{mg}$ daily) & 0.12 & 0.72 \\
ARISTOTLE (apixaban & $0.80(0.67-0.95)$, & $0.7 \mathrm{I}(0.6 \mathrm{I}-0.8 \mathrm{I})$, \\
5 mg twice daily) & 0.012 & $<0.000 \mathrm{I}$ \\
ENGAGE AF & $0.88(0.75-\mathrm{I} .02)$, & $0.80(0.7 \mathrm{I}-0.90)$, \\
(edoxaban 60 mg daily) & 0.10 & 0.0002 \\
Combined & $0.8 \mathrm{I}(0.73-0.9 \mathrm{I})$, & $0.86(0.73-\mathrm{I} .00)$, \\
& $<0.000 \mathrm{I}$ & 0.06
\end{tabular}

Note: Data from Ruff et al. ${ }^{50}$

Abbreviations: $\mathrm{RR}$, relative risk; $\mathrm{Cl}$, confidence interval. 
shown to be superior to warfarin in stroke prevention compared to warfarin with less bleeding, and has been approved for this indication by the FDA since 2012, but its twice-aday dosing raises concerns about medication compliance. Once-daily dosing of edoxaban is backed by a large Phase II trial (unlike rivaroxaban), and has a definite advantage when compared to medications administered twice a day (dabigatran and apixaban). This is especially important, as NVAF patients need lifelong therapy, and ease of administration is paramount for medication compliance. Since both doses of edoxaban have been proven to be efficacious in stroke prevention, the clinician had the potential choice of using low-dose edoxaban in patients with high bleeding risk and high doses in patients with low bleeding risk and high thromboembolic risk.

Excessive strokes were seen in the immediate period of transition from rivaroxaban and apixaban to warfarin in the ROCKET-AF and ARISTOTLE trials. This was due to an inability to achieve an adequate overlap from the discontinuation of an NOAC (with a short half-life) and the delay in achieving therapeutic INR with warfarin. The ENGAGE AF-TIMI 48 investigators designed a 14-day overlap protocol, and the choice of OAC at the end of the trial (VKA or an NOAC) was made by the physician and patient. In patients changing over to VKA, a 14-day transition kit of half-dose edoxaban was utilized and early and frequent INR testing was implemented. A warfarin-titration algorithm was used to ensure the adequacy of VKA therapy. No difference in stroke and bleeding rates were observed in groups that transitioned from edoxaban to warfarin and vice versa. ${ }^{51}$

NOACs have been evaluated in special situations like elective cardioversion for patients with NVAF. Dabigatran, rivaroxaban, and apixaban have been shown to be as efficacious as warfarin in stroke prevention in patients undergoing cardioversion, with low stroke rates seen in all groups. ${ }^{53-55}$ A current multicenter randomized interventional trial (ENSURE-AF, NCT02072434) is enrolling patients to evaluate edoxaban for this indication.

An important caveat to the use of NOACs compared to warfarin has been the unavailability of effective reversal agents. PER977 has been tested in preclinical studies in reversing the anticoagulant effects of edoxaban, and has shown promise. ${ }^{56}$ The clinical availability of such an antidote may prove to be a definite advantage in favor of edoxaban.

\section{Clinical implications and future direction}

Edoxaban could be an excellent alternative for stroke prevention in NVAF patients who are either intolerant to warfarin or have difficulty in maintaining therapeutic levels due to dietary or medication interactions. It would be ideal in patients with compliance issues, due to the convenient daily dosing. With dose reduction, edoxaban can be used in patients on antiarrhythmics like amiodarone, dronedarone, and verapamil. It has also been shown to be safe and efficacious in patients with moderate renal dysfunction.

Edoxaban was recently presented before the FDA advisory panel. One of the major issues that were debated in this meeting was the subgroup analysis in patients with creatinine clearance $\geq 80 \mathrm{~mL} / \mathrm{min}$. In these patients with normal renal function, edoxaban use was associated with higher incidence of stroke and SEE. Both doses fared worse than dose-adjusted warfarin (HR for primary end point in edoxaban $60 \mathrm{mg}$ versus warfarin was 1.41 [95\% CI 0.97-2.05]). This resulted in one vote against the approval of edoxaban. However, citing the inherent pitfalls in interpreting subgroup analysis, especially when it went against the overall results of the trial, the Cardiovascular and Renal Drugs Advisory Committee voted nine to one in favor of approving edoxaban for the prevention of stroke and SEE in patients with NVAF. ${ }^{57}$ Like other NOACs, edoxaban is being tested in clinical situations other than NVAF warranting anticoagulation. With further investigation, wider future application can be anticipated.

\section{Summary}

$\mathrm{AF}$ is the most common arrhythmia, and is a risk factor for cardioembolic strokes. Warfarin has traditionally been used for stroke prevention, but its use is limited by a narrow therapeutic window, significant drug-drug and drug-food interactions, need for frequent monitoring, and bleeding complications. The last decade has seen the advent of NOACs. Dabigatran, rivaroxaban, and apixaban have been approved by the FDA for stroke prevention in patients with AF. Edoxaban is the newest factor $\mathrm{Xa}$ inhibitor that has been evaluated in the largest randomized controlled trial of all NOAC trials. High-dose edoxaban is superior and low-dose edoxaban noninferior to warfarin in preventing strokes and SEEs. Hemorrhagic strokes were lower with both doses, as were all major and intracranial bleeding. Gastrointestinal bleeding was lower than warfarin in the low-dose edoxaban group. Cardiovascular death was lower with edoxaban at both doses. Edoxaban has recently been recommended for approval by the FDA advisory committee. Once available, it promises to be a safe and effective tool for stroke prevention in patients with AF.

\section{Disclosure}

PD serves as a consultant for Pfizer DSI and speaker for BMS/Pfizer. The authors report no other conflicts of interest in this work. 


\section{References}

1. Giugliano RP, Ruff CT, Braunwald E, et al. Edoxaban versus warfarin in patients with atrial fibrillation. N Engl J Med. 2013;369:2093-2104.

2. Wolf PA, Abbott RD, Kannel WB. Atrial fibrillation as an independent risk factor for stroke: the Framingham Study. Stroke. 1991;22:983-988.

3. Benjamin EJ, Wolf PA, D'Agostino RB, Silbershatz H, Kannel WB, Levy D. Impact of atrial fibrillation on the risk of death: the Framingham Heart Study. Circulation. 1998;98:946-952.

4. Kannel WB, Wolf PA, Benjamin EJ, Levy D. Prevalence, incidence, prognosis, and predisposing conditions for atrial fibrillation: population-based estimates. Am J Cardiol. 1998;82:2N-9N.

5. Miller PS, Andersson FL, Kalra L. Are cost benefits of anticoagulation for stroke prevention in atrial fibrillation underestimated? Stroke. 2005;36:360-366.

6. Gage BF, Waterman AD, Shannon W, Boechler M, Rich MW, Radford MJ. Validation of clinical classification schemes for predicting stroke: results from the National Registry of Atrial Fibrillation. JAMA. 2001;285:2864-2870.

7. Olesen JB, Lip GY, Hansen ML, et al. Validation of risk stratification schemes for predicting stroke and thromboembolism in patients with atrial fibrillation: nationwide cohort study. BMJ. 2011;342:d124.

8. January CT, Wann LS, Alpert JS, et al. 2014 AHA/ACC/HRS guideline for the management of patients with atrial fibrillation: a report of the American College of Cardiology/American Heart Association Task Force on Practice Guidelines and the Heart Rhythm Society. J Am Coll Cardiol. 2014;64:e1-e76.

9. Hart RG, Pearce LA, Aguilar MI. Meta-analysis: antithrombotic therapy to prevent stroke in patients who have nonvalvular atrial fibrillation. Ann Intern Med. 2007;146:857-867.

10. Ogilvie IM, Newton N, Welner SA, Cowell W, Lip GY. Underuse of oral anticoagulants in atrial fibrillation: a systematic review. Am J Med. 2010;123:638-645. e4.

11. Holbrook AM, Pereira JA, Labiris R, et al. Systematic overview of warfarin and its drug and food interactions. Arch Intern Med. 2005;165: 1095-1106.

12. Nutescu EA, Shapiro N1, Ibrahim S, West P. Warfarin and its interactions with food, herbs, and other dietary supplements. Expert Opin Drug Saf. 2006;5:433-451.

13. Leonard MC. Interactions between herbs and cardiac medications. Pharmacother Update. 2001;4. Available from: http://www.clevelandclinicmeded.com/medicalpubs/pharmacy/MarApr2001/herbs_cardiac. htm. Accessed April 10, 2012.

14. Sarawate C, Sikirica MV, Willey VJ, Bullano MF, Hauch O. Monitoring anticoagulation in atrial fibrillation. J Thromb Thrombolysis. 2006;21: 191-198.

15. Jowett S, Bryan S, Mahé I, et al. A multinational investigation of time and traveling costs in attending anticoagulation clinics. Value Health. 2008;11:207-212.

16. Marinigh R, Lane DA, Lip GY. Severe renal impairment and stroke prevention in atrial fibrillation: implications for thromboprophylaxis and bleeding risk. J Am Coll Cardiol. 2011;57:1339-1348.

17. Tomura S, Nakamura Y, Doi M, et al. Fibrinogen, coagulation factor VII, tissue plasminogen activator, plasminogen activator inhibitor-1, and lipid as cardiovascular risk factors in chronic hemodialysis and continuous ambulatory peritoneal dialysis patients. Am J Kidney Dis. 1996;27:848-854.

18. Elliott MJ, Zimmerman D, Holden RM. Warfarin anticoagulation in hemodialysis patients: a systemic review of bleeding rates. Am J Kidney Dis. 2007;50:433-440.

19. Hart RG, Pearce LA, Aguilar MI. Meta-analysis: antithrombotic therapy to prevent stroke in patients who have nonvalvular atrial fibrillation. Ann Intern Med. 2007;146:857-867.

20. Heart Rhythm Society, Fuster V, Rydén LE, et al. ACC/AHA/ESC 2006 guidelines for the management of patients with atrial fibrillation-executive summary: a report of the American College of Cardiology/American Heart Association Task Force on Practice Guidelines and the European Society of Cardiology Committee for Practice Guidelines (Writing Committee to Revise the 2001 Guidelines for the Management of Patients with Atrial Fibrillation). J Am Coll Cardiol. 2006;48:854-906.
21. [No authors listed]. Stroke Prevention in Atrial Fibrillation Study. Final results. Circulation. 1991;84:527-539.

22. Connolly SJ, Eikelboom J, Joyner C, et al. Apixaban in patients with atrial fibrillation. $N$ Engl J Med. 2011;364:806-817.

23. ACTIVE Writing Group of the ACTIVE Investigators, Connolly S, Pogue J, et al. Clopidogrel plus aspirin versus oral anticoagulation for atrial fibrillation in the Atrial fibrillation Clopidogrel Trial with Irbesartan for prevention of Vascular Events (ACTIVE W): a randomised controlled trial. Lancet. 2006;367:1903-1912.

24. ACTIVE Investigators, Connolly SJ, Pogue J, et al. Effect of clopidogrel added to acetylsalicylic acid in patients with atrial fibrillation. $N$ Engl J Med. 2009;360:2066-2078.

25. Wann LS, Curtis AB, January CT, et al. 2011 ACCF/AHA/HRS focused update on the management of patients with atrial fibrillation (updating the 2006 guideline): a report of the American College of Cardiology Foundation/American Heart Association Task Force on Practice Guidelines. J Am Coll Cardiol. 2011;57:223-242.

26. Connolly SJ, Ezekowitz MD, Yusuf S, et al. Dabigatran versus warfarin in patients with atrial fibrillation. N Engl J Med. 2009;361: 1139-1151.

27. Southworth MR, Reichman ME, Unger EF. Dabigatran and postmarketing reports of bleeding. $N$ Engl J Med. 2013;368:1272-1274.

28. Connolly SJ, Wallentin L, Ezekowitz MD, et al. The Long-Term Multicenter Observational Study of Dabigatran Treatment in Patients With Atrial Fibrillation (RELY-ABLE) Study. Circulation. 2013;128: 237-243.

29. De Caterina R, Husted S, Wallentin L, et al. General mechanisms of coagulation and targets of anticoagulants (Section I). Position Paper of the ESC Working Group on Thrombosis - Task Force on Anticoagulants in Heart Disease. Thromb Haemost. 2013;109:569-579.

30. Patel MR, Mahaffey KW, Garg J, et al. Rivaroxaban versus warfarin in nonvalvular atrial fibrillation. $N$ Engl J Med. 2011;365:883-891.

31. Fleming TR, Emerson SS. Evaluating rivaroxaban for nonvalvular atrial fibrillation - regulatory considerations. N Engl J Med. 2011;365: $1557-1559$

32. Granger CB, Alexander JH, McMurray JJ, et al. Apixaban versus warfarin in patients with atrial fibrillation. $N$ Engl J Med. 2011;365: 981-992.

33. Camm AJ, Lip GY, De Caterina R, et al. 2012 Focused update of the ESC guidelines for the management of atrial fibrillation: an update of the 2010 ESC guidelines for the management of atrial fibrillation. Developed with the special contribution of the European Heart Rhythm Association. Eur Heart J. 2012;24:2719-2747.

34. Skanes AC, Healey JS, Cairns JA, et al. Focused 2012 update of the Canadian Cardiovascular Society atrial fibrillation guidelines: recommendations for stroke prevention and rate/rhythm control. Can J Cardiol. 2012;28:125-136.

35. Matsushima N, Lee F, Sato T, Weiss D, Mendell J. Bioavailability and safety of the factor Xa inhibitor edoxaban and the effects of quinidine in healthy subjects. Clin Pharm Drug Dev. 2013;2:358-366.

36. Mendell J, TachibanaM, Shi M, Kunitada S. Effects of food on the pharmacokinetics of edoxaban, an oral direct factor Xa inhibitor, in healthy volunteers. J Clin Pharmacol. 2011;51:687-694.

37. Zafar MU, Vorchheimer DA, Gaztanaga J, et al. Antithrombotic effects of factor Xa inhibition with DU-176b: phase-I study of an oral, direct factor Xa inhibitor using an ex-vivo flow chamber. Thromb Haemost. 2007;98:883-888

38. Ogata K, Mendell-Harary J, Tachibana M, et al. Clinical safety, tolerability, pharmacokinetics, and pharmacodynamics of the novel factor Xa inhibitor edoxaban in healthy volunteers. J Clin Pharmacol. 2010;50: 743-753.

39. Bathala MS, Masumoto H, Oguma T, He L, Lowrie C, Mendell J. Pharmacokinetics, biotransformation, and mass balance of edoxaban, a selective, direct factor Xa inhibitor, in humans. Drug Metab Dispos. 2012;40:2250-2255.

40. Mikkaichi T, Yoshigae Y, Masumoto H, et al. Edoxaban transport via P-glycoprotein is a key factor for the drug's disposition. Drug Metab Dispos. 2014;42:520-528. 
41. Mendell J, Zahir H, Matsushima N, et al. Drug-drug interaction studies of cardiovascular drugs involving P-glycoprotein, an efflux transporter, on the pharmacokinetics of edoxaban, an oral factor Xa inhibitor. $\mathrm{Am}$ J Cardiovasc Drugs. 2013;13:331-342.

42. Mendell J, Lee F, Chen S, Worland V, Shi M, Samama MM. The effects of the antiplatelet agents, aspirin and naproxen, on pharmacokinetics and pharmacodynamics of the anticoagulant edoxaban, a direct factor Xa inhibitor. J Cardiovasc Pharmacol. 2013;62:212-221.

43. Zahir H, Matsushima N, Halim AB, et al. Edoxaban administration following enoxaparin: a pharmacodynamic, pharmacokinetic, and tolerability assessment in human subjects. Thromb Haemost. 2012;108: $166-175$.

44. Weitz JI, Connolly SJ, Patel I, et al. Randomised, parallel-group, multicentre, multinational phase 2 study comparing edoxaban, an oral factor Xa inhibitor, with warfarin for stroke prevention in patients with atrial fibrillation. Thromb Haemost. 2010;104:633-641.

45. Yamashita T, Koretsune Y, Yasaka M, et al. Randomized, multicenter, warfarin-controlled phase II study of edoxaban in Japanese patients with nonvalvular atrial fibrillation. Circ J. 2012;76:1840-1847.

46. Salazar DE, Mendell J, Kastrissios H, et al. Modelling and simulation of edoxaban exposure and response relationships in patients with atrial fibrillation. Thromb Haemost. 2012;107:925-936.

47. Ruff CT, Giugliano RP, Antman EM, et al. Evaluation of the novel factor Xa inhibitor edoxaban compared with warfarin in patients with atrial fibrillation: design and rationale for the Effective aNticoaGulation with factor xA next GEneration in Atrial Fibrillation - Thrombolysis In Myocardial Infarction study 48 (ENGAGE AF-TIMI 48). Am Heart J. 2010;160:635-641.

48. Giugliano RP, Ruff CT, Rost NS, et al. Cerebrovascular events in 21105 patients with atrial fibrillation randomized to edoxaban versus warfarin: Effective Anticoagulation with Factor Xa Next Generation in Atrial Fibrillation-Thrombolysis in Myocardial Infarction 48. Stroke. 2014;45:2372-2378.
49. De Caterina R, Husted S, Wallentin L, et al. New oral anticoagulants in atrial fibrillation and acute coronary syndromes: ESC Working Group on Thrombosis - Task Force on Anticoagulants in Heart Disease position paper. J Am Coll Cardiol. 2012;59:1413-1425.

50. Ruff CT, Giugliano RP, Braunwald E, et al. Comparison of the efficacy and safety of new oral anticoagulants with warfarin in patients with atrial fibrillation: a meta-analysis of randomised trials. Lancet. 2014;383: 955-962.

51. Ruff CT, Giugliano RP, Braunwald E, et al. Transition of patients from blinded study drug to open-label anticoagulation: the ENGAGE AF-TIMI 48 trial. J Am Coll Cardiol. 2014;64:576-584.

52. Culebras A, Messé SR, Chaturvedi S, Kase CS, Gronseth G. Summary of evidence-based guideline update: prevention of stroke in nonvalvular atrial fibrillation: report of the Guideline Development Subcommittee of the American Academy of Neurology. Neurology. 2014;82:716-724.

53. Nagarakanti R, Ezekowitz MD, Oldgren J, et al. Dabigatran versus warfarin in patients with atrial fibrillation: an analysis of patients undergoing cardioversion. Circulation. 2011;123:131-136.

54. Cappato R, Ezekowitz MD, Klein AL, et al. Rivaroxaban vs vitamin K antagonists for cardioversion in atrial fibrillation. Eur Heart $J$ 2014;35:3346-3355.

55. Flaker G, Lopes RD, Al-Khatib SM, et al. Efficacy and safety of apixaban in patients after cardioversion for atrial fibrillation: insights from the ARISTOTLE trial (Apixaban for Reduction in Stroke and Other Thromboembolic Events in Atrial Fibrillation). J Am Coll Cardiol. 2014;63:1082-1087

56. Ansell JE, Bakhru SH, Laulicht BE, et al. Use of PER977 to reverse the anticoagulant effect of edoxaban. N Engl J Med. 2014;371:2141-2142.

57. US Food and Drug Administration. FDA draft briefing document for the Cardiovascular and Renal Drugs Advisory Committee (CRDAC). 2014. Available from: http://www.fda.gov/downloads/AdvisoryCommittees/ CommitteesMeetingMaterials/Drugs/CardiovascularandRenalDrugs AdvisoryCommittee/UCM420704.pdf. Accessed January 11, 2015.
Core Evidence

\section{Publish your work in this journal}

Core Evidence is an international, peer-reviewed open-access journal evaluating the evidence underlying the potential place in therapy of drugs throughout their development lifecycle from preclinical to postlaunch. The focus of each review is to evaluate the case for a new drug or class in outcome terms in specific indications and patient groups

\section{Dovepress}

The manuscript management system is completely online and includes a very quick and fair peer-review system, which is all easy to use. Visit http://www.dovepress.com/testimonials.php to read real quotes from published authors. 